\title{
Macropropagation and micropropagation of Ziziphus spina-christi
}

\author{
Mohammad Hassan Assareh ${ }^{(1)}$ and Hossein Sardabi(1)
}

${ }^{(1)}$ Research Institute of Forests and Rangelands, P. O. Box 13185-116, Tehran, Iran. E-mail: asareh@rifr-ac.ir, sardabi@rifr-ac.ir

\begin{abstract}
Christ's thorn (Ziziphus spina-christi (L.) Desf.) is a cross-pollinated plant with a wide range of genetic variability in nature and, for this reason, vegetative propagation assumes importance for improvement programs. The objective of this work was to evaluate cutting, T budding and tissue culture methods for this species. Shoots of 22-25 cm length were treated by two culture media and three shoot diameters for cutting trial. The $\mathrm{T}$ budding treatments consisted of three and five collection dates in spring and autumn, respectively. Tissue culture nodal segments bearing axillary buds were removed from shoots of mature trees at different seasons. Experiments to determine the best disinfectant chemical, appropriate conditions and materials to prevent phenolic compound exudation, explant characteristics, media type and cytokinin-auxin ratios were carried out. Successful rooting happened only on the sand beds and with cuttings greater than $8 \mathrm{~mm}$ diameter. The effects of $\mathrm{T}$ budding seasons on budtake percentage were significantly different. The best time for explant harvesting was mid of summer. Amount of rooting on media containing IBA as well as activated charcoal and disinfection with $\mathrm{Ca}(\mathrm{OCl})_{2}$ at concentration of $5 \%$ for 20 minutes were the best treatments.
\end{abstract}

Index terms: cutting, $\mathrm{T}$ budding, tissue culture, media.

\section{Macropropagação e micropropagação de Ziziphus spina-christi}

\begin{abstract}
Resumo - Ziziphus spina-christi (L.) Desf. é uma planta de polinização cruzada com grande variabilidade genética na natureza e, por isso, sua propagação vegetativa assume importância para o melhoramento genético. O objetivo deste trabalho foi avaliar os métodos de estaquia, borbulhia em T e cultura de tecido na propagação vegetativa desta espécie. No ensaio de estaquia, partes aéreas da planta com 22-25 cm foram cultivadas em dois meios de cultura e com três diâmetros. O ensaio de borbulhia consistiu na coleta do material em três datas na primavera e em cinco datas no outono. Os segmentos nodais contendo gemas axilares foram removidos da parte aérea de árvores maduras, em diferentes estações do ano, e avaliados em relação à esterilização química, exudação de compostos fenólicos e cultivo. O enraizamento ocorreu apenas em camas de areia e em estacas maiores do que $8 \mathrm{~mm}$. Houve efeito significativo da estação do ano sobre a porcentagem de brotação. O melhor período para coleta do explante foi no verão. O meio contendo IBA e carvão ativado apresentou maior quantidade de raízes e o melhor desinfestante foi $\mathrm{Ca}(\mathrm{OCl})_{2}$ na concentração de 5\%, por 20 minutos.
\end{abstract}

Termos para indexação: estaquia, borbulhia, meio nutritivo, estação do ano.

\section{Introduction}

Ziziphus spina-christi (L.) Desf. is a naturally distributed tree of subtropical, arid and semi-arid parts of Iran. The species is ecologically and economically important for its tolerance to drought and salinity, besides the high value of nonwood products, particularly fruit nutrition, leaves and shoots saponin, and tannin substrates (Weinges \& Schick, 1994; Mahran et al., 1996; Sudhersan \& Hussain, 2003). Since it is a crosspollinated plant and a wide range of genetic variability exists in nature, vegetative propagation, particularly in vitro propagation, assumes importance for mass and clonal propagation.

As seed of Ziziphus spina-christi requires scarification treatments to germinate (Moustafa et al., 1998), vegetative propagation plays a significant role in its improvement programs.

Budding has been studied mostly in Z. mauritiana. Headed eight-year-old Z. mauritiana (cv. Deshi) plants were budded with cv. Umran by two different methods and different seasons in 1993 at Bichpuri, India. Budding on July 28 or August 14 gave markedly higher budtake and budbreak percentage than budding on July 13. The 
patch budding method was significantly more effective than the modified ring method in respect of both budtake and budbreak. Using the patch method on August 14 and the modified ring method on July 28 gave the highest budtake (100) and budbreak (75) percentage. Temperatures after August 14 were more conducive for budtake and budbreak (Parmar et al., 1997).

Budding is the easiest method of vegetative propagation used for improved cultivars. Different types of budding techniques have been utilized with ring budding and shield-budding being the most successful. Wild varieties of ber $Z$. mauritiana are usually used as the rootstock, the most common being $Z$. rotundifolia in India and Z. spina-christi in Africa (Anonymous, 1998).

Stock and scion compatibility studies were conducted in ber cultivars with three rootstocks, viz Jhar ber (Z. nummularia) and two ecotypes of ber (Verma et al., 2000). The rootstock Jhar ber showed incompatibility with inverted bottleneck symptoms budded with Gola ecotype. All other combinations were compatible with perfect union.

Four budding methods (chip, patch, forket and T) were tried during May 1994-1995 by Nayak \& Sen, (2000) for ber (Z. mauritiana). Among the four methods, patch budding had the highest percentage of success (80), closely followed by the forkett method (70). Scion buds of Z. mauritiana collected from Jhargram, West Bengal, India, topworked on five-year-old trees of Z. rotundifolia, showed $80 \%$ to $100 \%$ budding success, two months after budding (Ghosh \& Mathew, 2002).

Various types of explants were examined in different in vitro experiments to evaluate several factors influencing regeneration of juvenile explants and callus of different species. For leaf and cotyledon explants of $Z$. mauritiana and Z. nummularia, root and hypocotyl callus regenerated with relatively high concentrations of NAA and BA (2.5 and $0.6 \mathrm{mg} \mathrm{L}^{-1}$, respectively). High number of shoots from tissues of both species was produced on medium containing nitrate $\mathrm{N}$ at $526.6 \mathrm{mg} \mathrm{L}^{-1}$. In vitro-formed shoots were rooted in White medium containing IBA (Mathur et al., 1993).

For stem explants of $Z$. mauritiana obtained from a mature tree, rooting was induced by pretreatment with $50 \mu \mathrm{M}$ indolebutyric acid or $50 \mu \mathrm{M}$ 1-naphthaleneacetic acid for 24 hours followed by transference to auxin-free White medium and plantlets grew well in a soil and vermiculite mixture (Mathur et al., 1995). For internodal and nodal segments, the explants were most responsive on the medium containing zeatin followed by BA (Nisha \& Srivastava, 1996). In leaf explants, high callusing was obtained on medium supplemented with $0.25 \mathrm{mg} \mathrm{L}^{-1}$ IBA and $2.5 \mathrm{mg} \mathrm{L}^{-1} \mathrm{BA}$ (Fougat et al., 1997). For shoot tips, shoot growth and number of nodes decreased with increasing BA concentration, while branching percentage increased (Sudhersan et al., 2001).

Buds of the small-fruited cultivar of $Z$. jujuba tended to develop shoots more actively than those of medium and large-fruited cultivars. The best results were obtained using a modified Pierik nutrient medium, with low BA and IBA concentrations. Cold treatment for 30 days in darkness facilitated embryo development and plant growth (Mitrofanova et al., 1994). For shoot tips, the best results were achieved on media containing $2.0 \mathrm{mg} \mathrm{L}^{-1}$ IBA or $0.05 \mathrm{mg} \mathrm{L}^{-1} \mathrm{IAA}+1.0 \mathrm{mg} \mathrm{L}^{-1}$ IBA. When cultured at $23-29^{\circ} \mathrm{C}, 20.95-38.8 \mu \mathrm{mol} \mathrm{m}^{-2} \mathrm{~s}^{-1}$, under a 12-hour photoperiod, rooting reached $99-100 \%$, with more than 5.3 rootlets per explant (Du et al., 1997).

Sudhersan \& Hussain (2003) developed a micropropagation protocol for Z. spina-christi which included three culture phases: initiation and multiplication, shoot growth and elongation and root formation. The initiation and multiplication medium contained $0.1-1.0 \mathrm{mg} \mathrm{L}^{-1} \mathrm{BA}$, the growth and elongation medium did not contain plant growth regulator (PGR) and the rooting medium contained $10 \mathrm{mg} \mathrm{L}^{-1}$ IBA. By the end of the three subcultures, about 300 explants were obtained from a single shoot tip.

The objective of this work was to evaluate the vegetative propagation methods, cutting, T budding and tissue culture for Ziziphus spina-christi.

\section{Material and Methods}

Three vegetative methods were examined to propagate $Z$. spina-christi: cutting, $T$ budding and tissue culture.

The $\mathrm{T}$ budding trial was conducted in 1999 in order to propagate seedless fruit variety of Z . spina-christi. Scions and rootstocks (diameter of $0.4-0.8 \mathrm{~cm}$ ) were provided from the seedless variety and the native trees of Christ's thorn, respectively. T budding was examined under factorial statistical method and completely random design, consisting of two season factors: spring, at three collection dates $\left(8^{\text {th }}, 15^{\text {th }}\right.$ and $28^{\text {th }}$ April $)$ and autumn, at five collection dates $\left(8^{\text {th }}, 13^{\text {th }}, 18^{\text {th }}\right.$ and $22^{\text {nd }}$ October, and $6^{\text {th }}$ November) and three replicates. Each plot consisted of 15 budded one-year-old seedlings. 
The cutting trial was conducted in 2000 under statistical design of split plots with three replicates, using shoots with $22-25 \mathrm{~cm}$ length, two culture substrate (sand and vermiculite) and three shoot diameters $(<8,8-16$ and $>16 \mathrm{~mm}$ ). The number of cuttings at each treatment was ten (total of 180 cuttings per trial). Shoots were cultured at the beginning of spring (March), at open environment in Dezful City, South Iran, $48^{\circ} 25^{\prime}$ East, $32^{\circ} 16^{\prime}$ North and altitude of $80 \mathrm{~m}$ above sea level. Irrigation was applied daily, particularly at warm seasons, by sprinkler, to provide an appropriate humid environment. Average annual precipitation was $250 \mathrm{~mm}$; average absolute maximum and minimum air temperature were $52^{\circ} \mathrm{C}$ and $-2^{\circ} \mathrm{C}$, respectively; average daily air temperature was $27^{\circ} \mathrm{C}$; soil type, sandy loam; climate according to improved de Martonne (Khalili, 1992) and Koppen systems were dry warm desert and Bw (dry desert) (Alijani \& Kaviani, 1992), respectively. The average monthly air temperature records during the trial are shown in Table 1.

The tissue culture trial was carried out in 2003 at Ahwaz city, South Iran, using nodal segments bearing axillary buds (4-8 buds under the apical bud) which have been removed from shoots of mature trees at end of winter, mid of summer and mid of autumn. The shoot segments were splitted to small pieces of $1.0-1.5 \mathrm{~cm}$ length and $0.5-0.8 \mathrm{~cm}$ diameter. After washing with tap water and dish washing detergent (Whitex), the pieces were washed with ethanol (70\%) for 30 seconds and then immediately washed with sterilized distilled water for three times. The method of Rathorae et al. (1992) was implemented to sterilize and culture the explants and to identify the best time of explant harvesting. After that, the explants were treated with three sterilization chemicals, including $\mathrm{HgCl}_{2}, \mathrm{NaOCl}$ and $\mathrm{Ca}(\mathrm{OCl})_{2}$ (0.05-0.5, 0.1-2.5 and 1.0-7.5\%, respectively), at different time intervals between 5 and 10 minutes, and under factorial statistical method and completely randomized blocks design.

Table 1. Average monthly air temperature during the experimental period in Dezful, Iran (2000-2002).

\begin{tabular}{lccc}
\hline Months & Maximum $\left({ }^{\circ} \mathrm{C}\right)$ & Minimum $\left({ }^{\circ} \mathrm{C}\right)$ & Average $\left({ }^{\circ} \mathrm{C}\right)$ \\
\hline March & 20.9 & 10.7 & 15.8 \\
April & 27.2 & 15.3 & 25.2 \\
May & 35.5 & 22.1 & 27.4 \\
June & 42.1 & 27.6 & 34.9 \\
July & 44.2 & 30.6 & 37.3 \\
August & 45.0 & 30.8 & 37.9 \\
September & 42.0 & 27.0 & 34.5 \\
\hline
\end{tabular}

After treatment of explants with the sterilizing components, they were washed ten times (two minutes at each time) with sterilized distilled water containing $100 \mathrm{mg} \mathrm{L}^{-1}$ ascorbic acid and $50 \mathrm{mg} \mathrm{L}^{-1}$ citric acid to avoid phenolic compound exudation during explant culturing. The disinfected explants were cultured on five basic media for shoot regeneration. The experimental media, MS, $\mathrm{C}_{2} \mathrm{D}$ (Chee \& Pool, 1987), WPM (Lloyd \& McCown, 1980), and DKW and DKW-G (Driver \& Kuniyuki, 1948), were free from PGR and contained $25 \mathrm{mg} \mathrm{L}^{-1}$ adenine sulfate and $30 \mathrm{~g} \mathrm{~L}^{-1}$ sugar. The media were supplied with $50 \mathrm{mg} \mathrm{L}^{-1}$ of ascorbic acid, $25 \mathrm{~g} \mathrm{~L}^{-1}$ of citric acid and $1.0 \mathrm{~g} \mathrm{~L}^{-1}$ of activated charcoal to prevent the browning phenomenon due to exudation of phenolic, mucilaginous and saponin compounds from the explants. The explant culture was performed under temperature of $28 \pm 2^{\circ} \mathrm{C}$, photosynthetic photon flux density (PPFD) of $65 \mu \mathrm{mol} \mathrm{m} \mathrm{m}^{-2} \mathrm{~s}^{-1}$ (for 16 hours) and relative humidity of $60 \pm 2 \%$.

Proliferation of explants was investigated using three types of media, based on MS, $7.5 \mathrm{mg} \mathrm{L}^{-1} \mathrm{BAP}$ and $0.01 \mathrm{mg} \mathrm{L}^{-1} \mathrm{IAA}, 7.5 \mathrm{mg} \mathrm{L}^{-1}$ Kinetin and $0.01 \mathrm{mg} \mathrm{L}^{-1}$ IAA and free from PGR. The regenerated shoots were transferred to a White liquid medium added by IAA, IBA or 4-CPA at concentration of $123 \mu \mathrm{mol} \mathrm{L}^{-1}$ for each treatment for the rooting process. The regenerated shoots were kept in the medium for 48 hours, then transferred to a White semi-solid medium, free from PGR with and without activated charcoal to investigate the effect of medium darkness on rooting. The variables were analyzed under factorial statistical method, completely randomized blocks design and t test (Duncan Method).

After three weeks, the plantlets were removed from the root media, washed, transferred to small pots containing sterilized rotten leaves (organic matter) and kept in a propagator with high humidity. Acclimatization was made through regular decline in humidity.

\section{Results and Discussion}

The variance analysis of the cutting trial showed that effects of the treatments and their interactions were significant on shoot rooting and growth. Rooting was successful only on the sand beds and cuttings larger than $8.0 \mathrm{~mm}$ and it was more effective (23\%) on shoots larger than $16 \mathrm{~mm}$ (Figure 1).

The $\mathrm{T}$ budding results (Table 2) show that the effects of budding seasons on budtake percentage were significantly different. The best budtake percentages were 
achieved on Oct.13 (80\%), Oct.18 (75.6\%) and Oct. 8 (71.1\%), respectively, and the worst budtake percentage was obtained on April 28 (51.1\%). Overall, there was no significant difference between the effect of end September and November. Other authors found different results, depending on method of budding, stocks and scions origins, age of rootstocks and site climate type. For instance, Singhrot et al. (1980) found thaT budding of $Z$. mauritiana in India was successfully performed in June-July (93.15\%) and Parmar et al. (1997) observed that eight-year-old budded trees of Z. mauritiana (cv. Deshi) with cv. Umran, using two different methods of budding and different seasons at Bichpuri, India, resulted in markedly higher budtake and budbreak percentage on July 28 or August 14 than on July 13. Using the patch method on August 14 and the modified ring method on July 28 gave the highest budtake (100) and budbreak (75) percentage.

The seasonal variation was found to be a vital factor in explant establishment, phenolic compounds production, fungal or bacterial infection. Explant harvesting at three different seasons resulted in different amounts of establishment and survival: spring (Feb. - Marc.), 10\%; autumn (Oct. - Nov.), 45\%; summer (July - Aug.), 69\%.

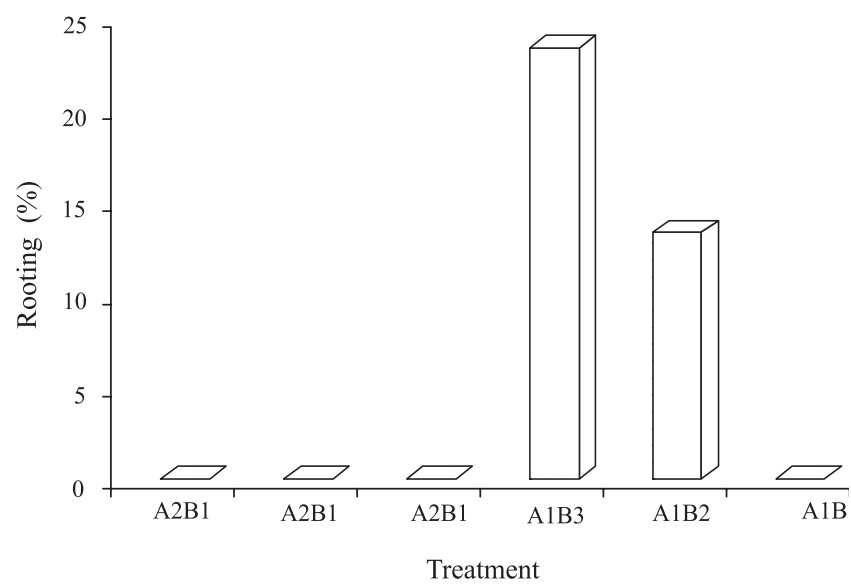

Figure 1. Effect of bed types [sand (A1) and vermiculite (A2)] and cutting diameter $(\mathrm{B} 1 \leq 8 \mathrm{~mm}, 8 \mathrm{~mm}<\mathrm{B} 2<16 \mathrm{~mm}$ and B3 $>16 \mathrm{~mm}$ ) on rooting percentage of Ziziphus spina-chistis.

Table 2. Effects of different seasons on budtake percentage of Ziziphus spina christi ${ }^{(1)}$.

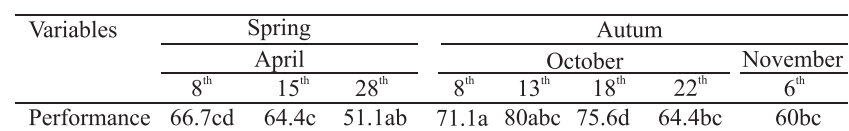

(1)Means followed by the same letter are not significantly different at $1 \%$ probability level by Duncan's Multiple Range test.
The best period for explant harvesting was mid of summer when the percentage of establishment increased up to 63.16. This was due to greatest vegetative growth of $Z$. spina-christi in summer. This is in contrast with the results obtained by Sudhersan \& Hussain (2003) for $Z$. spina-christi. They reported that shoot tips collected during summer failed to grow and develop into plantlets on PGR free media. Effect of seasonal variation on production of phenolic components of other species of Ziziphus and their subsequent influence on explant establishment rate were reported by Gill \& Gill (1994), Wang et al. (1994) and Assareh (1998), indicating the importance of explant harvesting of tropical forest species at appropriate season.

The results showed that among the disinfecting treatments for tissue culture explants, $\mathrm{Ca}(\mathrm{OCl})_{2}$ at concentration of $5 \%$ for 20 minutes was the best. Using $\mathrm{NaOCl}$ resulted mostly in explant infection whereas for $\mathrm{HgCl}_{2}$ resulted in tissue burning and medium browning. Implementation of $\mathrm{Ca}(\mathrm{OCl})_{2}$ with different concentrations, ranging between $1 \%$ and $10 \%$ for 20-30 minutes and their excellent effect on few forest species without tissue burning and effective decrease in explant infection, has been reported previously (Tombolatoe et al., 1991).

Five different tissue culture media were tested in order to find out the best nutrient composition. Sudhersand \& Hussain (2003) reported that among the different combinations of MS media used for Z. spina-christi, media without PGR enhanced shoot growth and elongation. The effects of different media on shoot growth were significantly different $(\mathrm{P}<0.05)$ and the shoot mass and length on DKW-G medium was significantly greater than on the other media (Table 3). This was in contrast to the results achieved by Fougat et al. (1997), who indicated that for nodal segments bearing an axillary bud and leaf pieces, bud break and shoot proliferation of $Z$. mauritiana were best on an MS medium supplemented with $0.025 \mathrm{mg} \mathrm{L}^{-1} \mathrm{NAA}$ and $1.0 \mathrm{mg} \mathrm{L}^{-1} \mathrm{BA}$.

Table 3. Effect of five different media on in vitro shoot growth of Ziziphus spina-christi ${ }^{(1)}$.

\begin{tabular}{lccc}
\hline Medium & Fresh weight $(\mathrm{g})$ & Dry weight $(\mathrm{g})$ & Shoot length $(\mathrm{mm})$ \\
\hline MS & $0.18836 \mathrm{ab}$ & $0.03441 \mathrm{ab}$ & $37.533 \mathrm{ab}$ \\
$\mathrm{C}_{2} \mathrm{D}$ & $0.18308 \mathrm{ab}$ & $0.02754 \mathrm{ab}$ & $40.667 \mathrm{ab}$ \\
WPM & $0.11658 \mathrm{~b}$ & $0.01753 \mathrm{~b}$ & $28.767 \mathrm{~b}$ \\
DKW & $0.20080 \mathrm{ab}$ & $0.03069 \mathrm{ab}$ & $31.567 \mathrm{ab}$ \\
DKW-G & $0.30457 \mathrm{a}$ & $0.04074 \mathrm{a}$ & $54.500 \mathrm{a}$ \\
\hline
\end{tabular}

(1) Means followed by the same letter are not significantly different at 5\% probability level by Duncan's Multiple Range test. 
The results for shoot generation trials showed that the $Z$. spina-christi plantlets grew very well at the different treatments (Figure $2 \mathrm{~A}$ ). They were able to

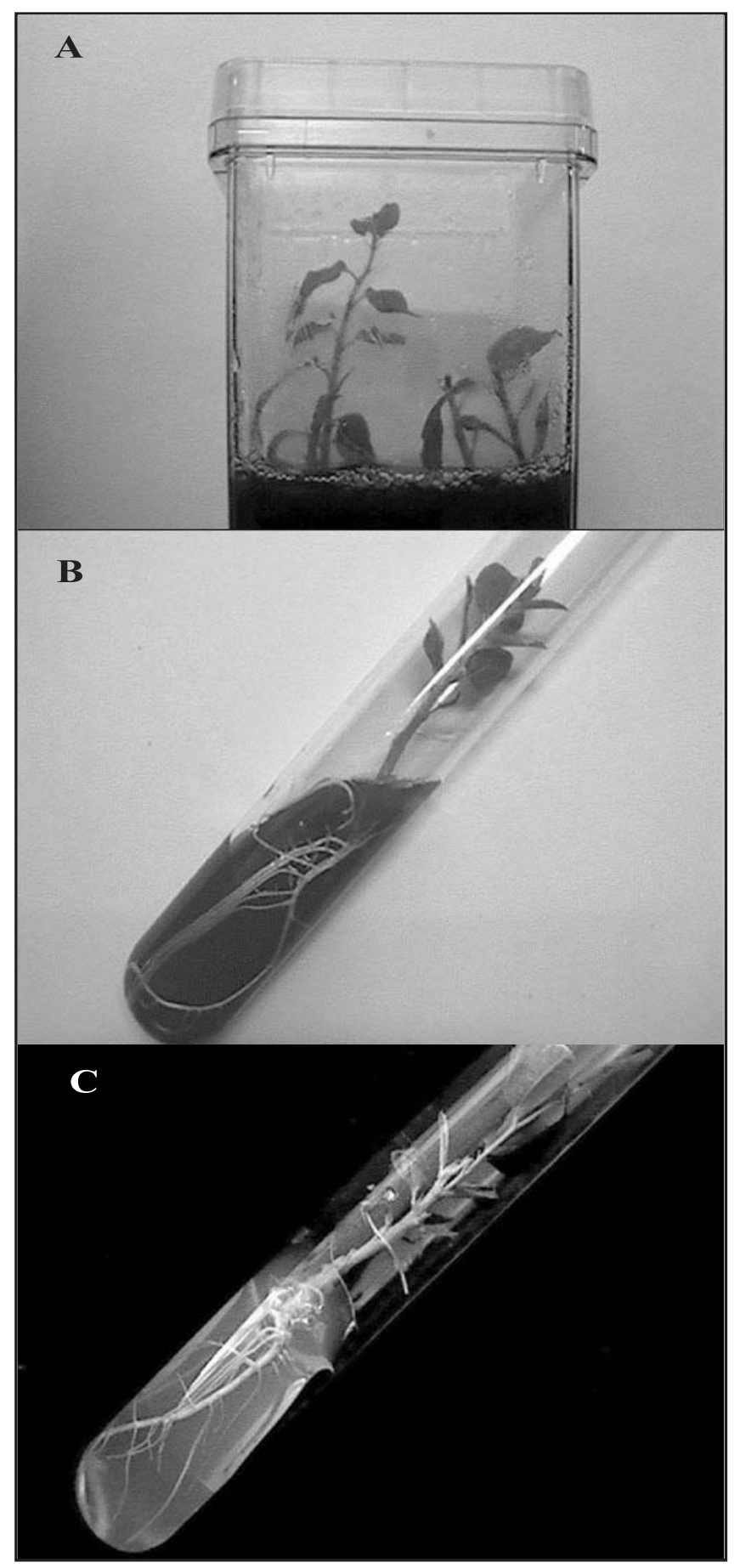

Figure 2. A: Established shoot in hormonal medium with $7.5 \mathrm{mg} \mathrm{L}^{-1}$ Kinotin and $0.01 \mathrm{mg} \mathrm{L}^{-1}$ IAA; B: Using media contaning activated charcoal for rooting; C: Using media without charcoal for rooting. produce single shoots and propagate well by fragmentation of apical shoots. The maximum time required for subculturing was four weeks. There was not significant difference between effect of MS media with or without PGR on shoot weight (fresh and dry) and length. This was in agreement with the results reported by George (1996), who indicated that choosing an appropriate PGR-free media was able to proliferate enough new buds and shoots. Sudhersan \& Hussain (2003) demonstrated that axillary branching and adventitious shoot regeneration in nodal segments were initiated only in the presence of low concentrations (0.01 $\left.\mathrm{mg} \mathrm{L}^{-1}\right)$ of cytokinin in the media. Lateral meristems inducement required further research, using wide range of growth regulator components and physical change in plant growth environment.

After four weeks the generated shoots grew sufficiently to be transferred to the rooting media. The results showed that using activated charcoal without hormones did not affect rooting significantly (Table 4), but the effects of hormones and interactions between hormone and activated charcoal on rooting was significantly different. Rooting was the greatest in media containing IAA and 4-CPA. In addition, media containing both activated charcoal and hormones increased rooting significantly, particularly with IBA (Figure $2 \mathrm{~B}$ and $\mathrm{C}$ ). According to the results achieved in this research, both activated charcoal and auxins (IAA, IBA, 4-CPA) enhanced rooting quantitatively and qualitatively. Sudhersan \& Hussain (2003) reported that root initiation was observed only in media containing $10 \mathrm{mg} \mathrm{L}^{-1}$ IBA and the percentage of adventitious root formation was only 30\%. Nissen \& Sutter (1990) found that increasing the concentration of auxin promoted rooting without callusing, due to an increasing concentration of activated charcoal, which had an effective role in absorption of some of the medium components. Other research has shown that activated

Table 4. Effect of different treatments on in vitro rooting of shoots regenerated from five nutritive media ${ }^{(1)}$.

\begin{tabular}{lccccc}
\hline $\begin{array}{c}\text { Activated } \\
\text { charcoal }(\mathrm{A})\end{array}$ & $\begin{array}{c}\text { Means } \\
(\mathrm{g})\end{array}$ & $\begin{array}{c}\text { Hormone }(\mathrm{H}) \\
(\mu \text { mol L })\end{array}$ & $\begin{array}{c}\text { Means } \\
(\mathrm{g})\end{array}$ & $\mathrm{A} \times \mathrm{H}$ & $\begin{array}{c}\text { Means } \\
(\mathrm{g})\end{array}$ \\
\hline With A $\left(\mathrm{A}_{2}\right)$ & $0.9984 \mathrm{a}$ & $123 \mathrm{IBA}\left(\mathrm{H}_{2}\right)$ & $0.3381 \mathrm{a}$ & $\mathrm{A}_{2} \mathrm{H}_{2}$ & $1.5811 \mathrm{a}$ \\
Without A $\left(\mathrm{A}_{1}\right)$ & $0.9335 \mathrm{a}$ & $123 \mathrm{IAA}\left(\mathrm{H}_{1}\right)$ & $0.8528 \mathrm{~b}$ & $\mathrm{~A}_{1} \mathrm{H}_{2}$ & $1.0950 \mathrm{ab}$ \\
& & $1234-\mathrm{CPA}\left(\mathrm{H}_{3}\right)$ & $0.7070 \mathrm{~b}$ & $\mathrm{~A}_{1} \mathrm{H}_{1}$ & $0.9984 \mathrm{ab}$ \\
& & & & $\mathrm{A}_{1} \mathrm{H}_{3}$ & $0.7071 \mathrm{~b}$ \\
& & & & $\mathrm{~A}_{2} \mathrm{H}_{1}$ & $0.7071 \mathrm{~b}$ \\
& & & $\mathrm{~A}_{2} \mathrm{H}_{3}$ & $0.7071 \mathrm{~b}$ \\
\hline
\end{tabular}

(1)Means followed by the same letter are not significantly different at 5\% probability level by Duncan's Multiple Range test. 
charcoal had an effective role in absorption of unknown components, which were produced through chemical processes within the media. Sometimes these unknown components played the role of growth inhibitor at morphogenesis stages. In addition, the activated charcoal, which eliminated light and provided a reasonable physical environment for the rhizosphere, prevents undesirable callusing and helps rooting (Nissen \& Sutter, 1990).

\section{Conclusions}

1. Budding is an alternative method for vegetative propagation of the elite trees of Z $\mathrm{Z}$. spina-christi, particularly where there is not enough technical and financial support for tissue culture method.

2. Tissue culture is the best method of vegetative propagation and summer is the best season for explant harvesting for Z. spina-christi.

3. $\mathrm{Ca}(\mathrm{OCl})_{2}$ at concentration of $5 \%$ for 20 minutes is effective for explant disinfection of $Z$. spina-christi.

4. All of the five PGR free media and the White liquid medium (mixed with activated charcoal and auxin) are useful for shoot and root explant regeneration of Z. spina-christi.

\section{References}

ALIJANI, B.; KAVIANI, M.R. Fundamentals in climatology (originally in Persian language). Iran: Organisation for Studying and Publishing Books of Human Sciences for Universities of Iran, 1992. 576p.

ANONYMOUS. Ziziphus mauritiana: a valuable tree for arid and semi-arid lands. FACT Sheet, v.98-103, p.2, 1998.

ASSAREH, M.H. In vitro plant regeneration through organogenesis somatic embryogenesis and photoautotrophic micropropagation of some Eucalyptus spp. 1998. 201p. Thesis (Ph.D.) - National University of Ireland, Dublin.

CHEE, R.; POOL, R.M. Improved inorganic media constituents for in vitro shoot multiplication of Vitis. Scientia Horticulturae, v.32, p.85-95, 1987.

DRIVER, J.A.; KUNIYUKI, A.H. In vitro propagation of paradox walnut rootstock (J. hindsii x J. regia). HortScience, v.9, p.507509, 1984.

DU, X.M.; GUO, H.P.; ZHAO, Y.J.; HE, X.H.; ZHU, W.R.; DU, X.M.; GUO, H.P.; ZHAO, Y.J.; HE, X.H.; ZHU, W.R. Techniques for promoting rooting and transplantation for in vitro explants of jujube. China Fruits, v.4, p.26-27, 1997.
FOUGAT, R.S.; JOGINDER, S.; TASHLIM, A.; ARHA, M.D.; GODHANI, P.R.; SINGH, J.; AHMED, T. In vitro studies in ber (Zizyphus mauritiana Lamk. cv. Gola). Journal of AppliedHorticulture Navsari, v.3, p.45-49, 1997.

GEORGE, E.F. Plant propagation by tissue culture: Part 2. In practice. $2^{\text {nd }}$ ed. England: Exegetics Limited, 1996. 1361p.

GILL, R.I.S.; GILL, S.S. In vitro exudation of phenols in Eucalyptus. Indian Forester, v.120, p.504-509, 1994.

GHOSH, S.N.; MATHEW, B. Performance of nine ber (Ziziphus mauritiana Lamk.) cultivars on top working in the semi-arid region of West Bengal. Journal of Applied Horticulture, v.4, p.49-51, 2002.

KHALILI, A. Dry and extra-dry climates of Iran (originally in Persian language). In: SEMINAR ON THE PROBLEMS OF IRANIAN DESERTS AND KAVIRS, 1992, May 17-20, Yazd, Iran. Proceedings. Yazd, Iran, [s.ed.], 1992. p.16-36.

LLOYD, G.; McCOWN, B. Commercially feasible micropropagation of mountain laurel, Kalmia latifolia, by use of shoot-tip culture. Proceedings of the International Plant Propagotors Society, v.30, p.421-427, 1980.

MAHRAN, G.D.H.; GLOMBITZA, K.W.; MIRHOM, Y.W.; HARTMANN, R.; MICHEL, C.G. Novel saponins from Ziziphus spina-christi growing in Egypt. Planta Medica, v.62, p.163-165, 1996.

MATHUR, N.; RAMAWAT, K.G.; SONIE, K.C. Plantlet regeneration from seedling explants of Ziziphus and silver nitrate and nutrient requirement for callus morphogenesis. Gartenbauwissenschaft, v.58, p.255-260, 1993.

MATHUR, N.; RAMAWAT, K.G.; NANDWANI, D. Rapid in vitro multiplication of jujube through mature stem explants. Plant Cell Tissue and Organ Culture, v.43, p.75-77, 1995.

MITROFANOVA, I.V.; CHEBOTAR, A.A.; MITROFANOVA, O.V. Capacity for in vitro morphogenesis in vegetative buds and embryos of Zizyphus jujuba Mill. as affected by maternal genotype and culture conditions. Russian Journal of Plant Physiology, v.41, p.722-727. Translated from Fiziologiya Rastenii, v.41, p.826-831, 1994.

MOUSTAFA, A.E.A.; EL-WAHAB, R.H.A.; HELMY, M.A.; BATANOUNY, K.H. Phenology, germination and propagation of some wild trees and shrubs in South Sinai, Egypt. Egyptian Journal of Botany, v.36, p.91-107, 1998.

NAYAK, G.; SEN, S.K. Standardization of budding methods of ber (Ziziphus mauritiana Lamk.). Environment and Ecology, v.18, p. 241-242, 2000.

NISHA, G.; SRIVASTAVA, P.S. In vitro regeneration and isozyme patterns in Ziziphus mauritiana. Journal of Plant Biochemistry and Biotechnology, v.5, p.87-90, 1996.

NISSEN, S.J.; SUTTER, E.G. Stability of IAA and IBA in nutrient medium to several tissue culture procedures. Horticultural Science,v.25, p.800-802, 1990.

PARMAR, A.S.; MEENA, K.S.; PUNEET, K.; KUMAR, P. Topworking on Deshi ber (Ziziphus mauritiana Lamk.) as affected by time and method of budding. Recent-Horticulture, v.4, p.39-42, 1997. 
RATHORAE, T.S.; SINGH, R.P.; DEORA, N.S.; SHEKHAWAT, N.S. Clonal propagation of Ziziphus species through tissue culture. Scientia Horticulturae, v.51, p.165-168, 1992.

SINGHROT, R.S.; MAKHIJA, M.; CHAUHAN, K.S. Vegetative propagation of ber (Ziziphus mauritiana Lamk.). IV. A note on the effects of different times of budding performance. Haryana Journal of Horticultural Science, v.9, p.40-42, 1980.

SUDHERSAN, C.; ABOEl-NIL, M.; HUSSAIN, J. In vitro propagation of Ziziphus mauritiana cultivar Umran by shoot tip and nodal multiplication. Current Science, v.80, p.290-292, 2001.

SUDHERSAN, C.; HUSSAIN, J. In vitro clonal propagation of a multipurpose tree, Ziziphus spina-christi (L.) Desf. Turkish Journal of Botany, v.27, p.167-171, 2003.
TOMBOLATOE, A.F.C.; TAKEBAYASHI, S.S.G.; COSTA, A.M.; QUIRNO, F.A. In vitro culture of bromeliads. Agronomica, v.43, p.77-79, 1991.

VERMA, M.K.; SHARMA, V.P.; SAXENA, S.K. Compatibility of ber (Ziziphus mauritiana Lamk.) varieties on different rootstocks. Indian Journal of Horticulture, v.1, p.13-17, 2000.

WANG, Q.; TANG, H.; ZHOU, H. Phenol induced browning and establishment of shoot-tip explants of fuji apple and jinhua pear cultured in vitro. Journal of Horticultural Science, v.69, p.833839, 1994.

WEINGES, K.; SCHICK, H. Dodecaacetyl prodel phinidin B3 from the dried leaves of Ziziphus spina-christi. Phytochemistry, v.38, p.505-507, 1994.

Received on April 5, 2004 and accepted on November 25, 2004 